\title{
The role of mentoring in the dual system of youth education in the period of digitalization of society
}

\author{
Zhanar Duskazieva ${ }^{1, *}$ \\ ${ }^{1}$ Kazakhstan University of Innovative and Telecommunication Systems, Uralsk, Kazakhstan
}

\begin{abstract}
In Kazakhstan, there are colossal changes in the entire education system, which should lead to radical transformations not only in education, but also in the entire economy. In the republic, one of the most promising novelties in modern educational technologies is dual education. Since the development of the economy requires an influx of qualified personnel, in recent years the demand for trained and competent specialists has been growing. However, it is not a secret for anyone that the knowledge and business, working skills of the majority of graduates of educational institutions - specialized, higher - do not completely coincide with the real requirements of industries, companies, organizations. As a rule, it requires additional teaching to get the right specialist, which, in turn, takes time and money for additional training, and besides, there are losses in the work process due to the inferiority of the employee. Hence the necessity follows dictated by the life itself, in the process of training future specialists, along with theoretical knowledge, to teach practical skills oriented towards real production and organization It also makes sense to partly orient the theoretical basis of training to a specific production, business process. In fact, we are talking about a kind of symbiosis of theory and practice, for the implementation of which we need different actions. State - for the legislative basis of dual education. Scientific - for the preparation of guidelines for the organization of this form of training. Organizational - for the formation of new target associations, such as research and production centers, various collaborations of educational and industrial, business formations. At the same time, a special role in the implementation of dual technologies is assigned to mentoring young people.
\end{abstract}

\section{Introduction}

The aim of the study was to understand such type of teaching as dual technologies in education, in which the theoretical part of the training of students takes place on the basis of educational institutions, and the practical part - at the workplace in organizations that create conditions for the most effective pedagogical process.

A review analysis of the literature clearly related to this problem revealed trends in the development of the education system, and above all, the important structure of higher

\footnotetext{
*Corresponding author: asel36@mail.ru
} 
education specialties. In this vein, the following works were interesting: A.A. Verbitsky [1] and O. A. Ulyanina [2] - on the study of a new educational paradigm in Russian education; Sudhoff M., Prinz H., Kulenketter B. [3] - on practice-oriented learning in Germany; G. Abdiraimova, S. Duisenova, S. Shayakhmetova [4, 5] - on the assessment of the quality of higher education in Kazakhstan; A. Beissenova, D. Shormanbayeva, D. Sundetbayev [6], Shormanbayeva D., Abdigaliyeva G., Karassartova M., Sivodedova A., Balshikeyeyv S. [7], Kaufman N. Yu. [8] - on the peculiarities of the transformation of the value system of the Kazakh society in the education system; Zh. Myrkhalykova, A. Aydarova, M. Seidakhmetovts, A. Abishovad, E. Dosmuratova [9] - on the integration of new forms of education and science in the Republic of Kazakhstan; Gambeeva, Yu.N., \& Sorokina, E.I. [10] and Kenzhebayev Gabit K., Dalayeva Tenlik T. [11] - on the implementation of elearning; Koudahl P. D. [12] - on the possibilities of transition of the education system to dual education. As the analysis has shown, the leading professions that welcome dual training are: "Finance", "Accounting and Audit", "Economics", "Jurisprudence", "Process Engineer", "Engineering Technician". However, according to statistics, it is stated that such a number of specialists (financiers, auditors, accountants, lawyers, engineers) is not appropriate for the economy of Kazakhstan.

A review of foreign literature has shown that this topic is relevant for Western society and the emphasis in scientific works is placed on the training of specialists in medical, engineering, economic and management areas in dual training. In this vein, the following works were interesting: Wiesner C. \& Horizonte B. [13], Rosa Li [14], Ana del Carmen \& etc. [15], Paul-Emmanuelle Anckaert \& etc. [16], B. Schulrufa \& R. Turner, Hattie J. [17], Beddewela E. [18], all the works of Western colleagues describe the problems of ecology and safety when switching to a dual training system, which does not reflect our request for studying precisely the role of mentoring in the dual education system of youth in the period of digitalization of society. Unfortunately, educational organizations devote most of the educational process to theoretical training, while only about $10 \%$ of the curriculum remains for practical classes. As a result, young specialists graduated from colleges, technical schools and universities, having entered real production, are helpless at first. At the same time, the employer does not have the time and often the opportunities for additional training of young specialists in practical skills. Nevertheless, there is a way to solve this problem - dual training. In this paper, we focus on the experience of Kazakhstan, since the author lives and works in this republic.

\section{Materials and methods}

The main objective of the study was to identify the value orientation of students. For this purpose, we used the methodology of M. Rokeach [19], where two classes of values were studied: terminal values - beliefs that the ultimate goal of individual existence is worth striving for. The incentive material was presented as a set of 18 values; and instrumental values - beliefs that some way of acting or personality trait is preferable in any situation. The incentive material was also presented with a set of 18 values. This kind of division corresponds to the traditional division into values - goals and values - means. The study was carried out on a longitudinal basis, and cross-sections of responses were obtained in 2019 and 2020 (during the period of self-isolation of student youth). 2681 students in various areas of professional training were interviewed. 


\section{Result}

The study was conducted twice, the first in 2019 and the second in 2020, when students were in self-isolation and had to study remotely.

The data obtained are presented in Table 1.

Table 1. Average indicators of the significance of the types of values according to the method of M. Rokeach in the group of students.

\begin{tabular}{|c|c|c|}
\hline List of terminal values & $\begin{array}{c}\text { Initial } \\
\text { diagnostics, } 2019\end{array}$ & $\begin{array}{c}\text { Repeated } \\
\text { diagnostics, } 2020\end{array}$ \\
\hline \multicolumn{3}{|c|}{ Terminal values } \\
\hline Active life & 3.40 & 3.45 \\
\hline Life wisdom & 3.18 & 3.20 \\
\hline Health & 4.00 & 3.20 \\
\hline Interesting work $-\mathrm{T}^{*}$ & 4.35 & 2.90 \\
\hline Beauty of nature and art & 3.40 & 3.45 \\
\hline Love & 4.26 & 4.30 \\
\hline Financially secure life $-\mathrm{T}^{*}$ & 3.45 & 2.70 \\
\hline Having loyal and good friends & 4.00 & 4.15 \\
\hline Public recognition $-\mathrm{T}^{*}$ & 3.30 & 2.81 \\
\hline Calm in the country, peace & 3.00 & 3.80 \\
\hline Cognition, intellectual development $-\mathrm{T}^{*}$ & 3.60 & 2.60 \\
\hline Productive life $-\mathrm{T}^{*}$ & 3.80 & 2.90 \\
\hline Development - $\mathrm{T}^{*}$ & 4.00 & 2.87 \\
\hline Entertainment & 3.25 & 3.20 \\
\hline Liberty & 3.20 & 3.20 \\
\hline Happy family life & 3.15 & 3.55 \\
\hline Happiness of others & 3.16 & 3.56 \\
\hline Creative activity & 3.25 & 3.30 \\
\hline Self-confidence & 3.29 & 3.30 \\
\hline \multicolumn{3}{|c|}{ Instrumental values } \\
\hline Accuracy & 3.30 & 3.30 \\
\hline Politeness & 3.35 & 3.85 \\
\hline High requests & 3.00 & 3.00 \\
\hline Cheerfulness & 4.15 & 4.50 \\
\hline
\end{tabular}




\begin{tabular}{|c|c|c|}
\hline Diligence - I* & 3.18 & 2.40 \\
\hline Independence & 3.54 & 3.54 \\
\hline $\begin{array}{c}\text { Intransigence to one's own and other people's } \\
\text { disadvantages }\end{array}$ & 3.40 & 2.30 \\
\hline Knowledge - I* & 3.44 & 2.00 \\
\hline Responsibility - I* & 4.45 & 3.30 \\
\hline Rationalism (the ability to make informed decisions) & 4.35 & 4.45 \\
\hline Self-control - I* & 3.56 & 2.40 \\
\hline Courage in defending your opinion & 3.40 & 3.50 \\
\hline Firm will - I* & 3.41 & 2.60 \\
\hline Tolerance for the opinions of others & 3.20 & 3.20 \\
\hline Honesty & 4.12 & 4.15 \\
\hline Sensitivity & 4.00 & 4.00 \\
\hline Open mindedness - I* & 3.84 & 2.20 \\
\hline Efficiency in business - I* & 3.43 & 2.50 \\
\hline
\end{tabular}

The individual hierarchy of values obtained as a result of the study was divided by color into those that underwent significant changes in the process of longitudinal research and into three equal groups:

- preferred values, significant (ranks from 1 to 6);

- indifferent (7-12);

- rejected, insignificant (13-18 rank of the hierarchy).

In 2019 , in the group of subjects, the values were distributed as follows. The most significant terminal values are "interesting work" (4.35), "health" (4.00), "development" (4.00), "productive life" (3.80), "cognition, intellectual development" (3.60), "financially secure life" (3.45), "public recognition" (3.00). The least significant values are "calmness in the country, peace" (3.00), "entertainment" (3.20), and "happy family life" (3.15). Students are mainly oriented towards entertainment and family.

At the same time, the analysis of data on "instrumental values" revealed the following picture: the respondents value such qualities as "responsibility" (4.45), "open-mindedness" (3.84), "self-control" $(3,56)$, "knowledge" (3.44), "efficiency in business" (3.43), "strong will" (3.41), as well as "diligence" (3.18). Instrumental values confirm persistence, a strong will to pursue one's interests.

\section{Discussion}

Studies carried out in 2019 regarding the acquisition of higher education for students showed that, as a rule, its obtaining is necessary for the prestige, self-satisfaction of students and their parents, and not so much for obtaining relevant knowledge. Practice shows that a graduate needs a formal document that provides an opportunity to get a job. It can be noted that until 2019, an educational institution with traditional technologies of pedagogical processes 
transferred to students the baggage of completely unnecessary knowledge and competencies, most of which were not in demand by the student or were outdated.

It is this fact that explains the presence of the problem of the need for the transition to dual technologies of education. This conclusion is further confirmed by the value attitudes of students in 2020 during the forced transition to distance education in Kazakhstan. The study has shown that the lower the rank of the scale, the higher the value of this value for students. Thus, we obtained the following indicators of the distribution of values in the whole group of subjects: the most significant terminal values are "cognition, intellectual development" (2.60), "financially secured life" (2.70), "interesting work" (2.80), "public recognition" (2.81), "development" (2.87), "productive life" (2.90), "health" (3.20). It can be noted that the period of self-isolation made students to reassess values towards consciously obtaining higher education and development.

In turn, the analysis of data on "instrumental values" clearly showed that the respondents had the highest rank for "education" (2.00), "open-mindedness" (2.20), "self-control" (2.40), "diligence" (2.40), "efficiency in business" (2.50), "strong will" (2.60), "responsibility" (3.30).

In a number of countries, there is experience of dual training already accumulated for centuries. For example, in Germany, known for its labor traditions of the country, for many centuries to the present, young people who have chosen the path of the artisan are trained in special educational institutions, where ordinary school education is combined with production, and craftsmen pass on their experience in training workshops.

If we talk about Kazakhstan, at present, there are a number of industrial training systems here, each has its own pros and cons, but so far there is no basic one that could be considered recommended for distribution.

In many cases, students themselves form their own system of dual education, choosing a combination of study at the institute and production. In the republic, approximately $50 \%$ of university students have an extramural form of study. For example, 60 to $70 \%$ of those receiving education in the popular specialties "Finance" and "Jurisprudence" are extramural students, most of whom, as a rule, especially in senior courses, combine their studies with work in their specialty.

Of course, in the above situations, we are talking about spontaneous, independent dual education, the effectiveness of which depends on the case. However, there is a number of problems that need to be resolved in the organized joint training in academic disciplines and production skills. First of all, these are shortcomings on a national scale: insufficiently clear laws and regulations governing the dual training system. There are no modern educational standards for this technology. There is a catastrophic lack of investments, because few are attracted by investing money in training specialists, since a considerable time will pass before they return. A number of such tasks should be solved by the relevant ministry, since there are most of the management problems here.

That is, summarizing the current tasks of the development of dual education in Kazakhstan, it is necessary to prepare a normative base, develop a national model of teaching young people in dual programs, form specialized dual training centers on the basis of existing universities and enterprises, and also, in order to further improve, to organize a system for monitoring the effectiveness of dual education introduced in the republic. The result of such work will be the correspondence of the knowledge of young specialists to the needs of the real economy.

We note right away that we are not talking about creating a kind of universal system of dual education for all specialties and industries, this is practically impossible. In practice, labor processes in different organizations are certainly different. Therefore, in each specific situation, it is necessary to build training of specialists in production skills in accordance with 
the content of the labor process, as well as to organize relationships with theoretical studies at the university.

If we consider the main forms of labor, then in its physical hypostasis it is possible to single out operational and operational-complex systems built on the implementation of certain techniques, actions, operations and technological processes directly at the workplace (workshop, office).

With regard to intellectual work, when organizing dual education, it is necessary to take into account the following: the components of the personality-activity approach. Such actions make it possible to find and realize the individual entry of the student mastering the profession into the given work process of the organization; components of the competencebased approach, in which, taking into account the individual properties of the trained specialist, it is possible to build a system of his personal growth in order to obtain a qualified employee; components of the contextual approach, which makes it possible to link the content of industrial and theoretical education with the specifics of the profession; components of the professiographic approach aimed at constructing a professiogram. That network is about the aggregate characteristics of the results of vocational education of young professionals and allows assessing the individual professional trajectory of a student.

Today, when the whole world is experiencing a pandemic situation and, in connection with it, self-isolation, educational institutions have switched to remote education. A great burden falls on the shoulders of university teachers, they have to hastily reorient themselves to mastering digital technologies for the educational process. At the time of the audience with a group of students in the Internet space, the teacher is a representative of the university and his duties also include maintaining students' motivation to study in a remote format. Thus, as noted by Yermentayeva A., Naimanbaieva K., L. Sultanbayevac, Uaidullakyzydd E., Niyetbayeva G., the teacher not only provides theoretical training, but is also forced to develop the competencies of practice-oriented approach more responsibly, thereby motivating the student to desire to learn, self-education, gain knowledge on their own, do homework responsibly, which subsequently distracts the student from depressive states [20].

When faced with the situation of self-isolation, different psychotypes of students are revealed, who master the curriculum in different ways, someone even outstrips their classmates and is forced to enter an individual trajectory of mastering the curriculum. Such students require special intermediate or state final certification.

Summarizing the views expressed in this paper, the following conclusions can be drawn. Mentoring today may look like one of the forms of investment in the development of a future specialist, as a symbiosis of an educational organization and a functioning economic organization, where dual education technologies are implemented in the form of a practiceoriented process of transferring knowledge, skills and abilities in order to form qualified specialists who can be immediately, without long-term adaptation included in the workflow of an enterprise, office, etc.

The organizational framework for mentoring is determined by: three-year (two-year - for undergraduates), or one-year term of study; contractual documents on dual training with the subsequent recruitment of graduates of an educational institution by interested organizations; an agreement on dual training between an educational institution and a student; a document fixing control tests of graduated specialists, for example, industrial exams, a certificate confirming the development of dual technologies, etc.

The goals of mentoring: teaching students personal professional skills with their obligatory adaptation to the dual technology of education used in this educational institution; exact time management of classes with trainees; correction of the personal characteristics of students, based on the degree of their compliance with the chosen professions; transfer of the most modern experience in the organization of labor and working methods for a given specialty; the formation of motives among students for subsequent strong labor relations with 
fellow workers and the enterprise, as well as for the development of the corporate culture of the organization.

Participation of the mentor in the organization of dual training: the most qualified employees of the enterprise become mentors voluntarily and are appointed by the management by order of the organization, while the candidacy is agreed with the educational institution.

Mandatory qualities of a mentor are: mastery of the basics of pedagogy, as well as methods of modern vocational training and education; knowledge of the basics of the legal aspects of labor organization; the ability to apply the basic regulations on labor protection and fire safety in the workplace.

\section{Conclusions}

Dual education is an effective and modern training program for specialists. There are already numerous examples that graduates of colleges, where such training is practiced, are positively assessed by employers. Such specialists quickly become active participants in production processes. The primary task of the government of Kazakhstan is to interest entrepreneurs in partnership with educational institutions to organize dual education and ultimately receive a strong skilled crew of specialists, builders of the domestic economy.

The paper concludes that there is a spontaneous transition to dual education technologies, using the Internet space and new forms of knowledge transfer in a remote format, where an important role is given to a professional teacher - mentor.

The foregoing allows concluding: the development of a mentoring school in the preparation of practice-oriented specialists in Kazakhstan is a popular topic and a generator of new directions in the formation of dual education technologies. The development of this topic can significantly help in understanding the situation in modern education in Kazakhstan as a whole and outline ways to improve the dual technologies of education during the period of digitalization of society.

\section{References}

1. A.A. Verbitsky, The Education and science journal 6, 5-18 (2012) https://doi.org/10.17853/1994-5639-2012-6-5-18

2. O.A. Ulyanina, Psychological and pedagogical research 10(2), 135-147 (2018) DOI: https://doi.org/10.17759/psyedu.2018100212

3. M. Sudhoff, C. Prinz, B. Kuhlenkötter, Procedia Manufacturing 45, 114-120 (2020) doi: 10.1016/j.promfg.2020.04.081

4. G. Abdiraiymova, S. Duisenova, S. Shayakhmetov, Procedia - Social and Behavioral Sciences 116, 4315-4321 (2014) doi: 10.1016/j.sbspro.2014.01.939

5. G. Abdiraiymova, S. Duisenova, S. Shayakhmetov, Procedia - Social and Behavioral Sciences 8, 397-403 (2013) doi: 10.1016/j.sbspro.2013.06.282

6. A. Beissenova, D. Shormanbayeva, D. Sundetbayev, Procedia - Social and Behavioral Sciences 140, 168-171 (2014) doi: 10.1016/j.sbspro.2014.04.404

7. D. Shormanbayeva, G. Abdigaliyeva, M. Karassartova, A. Sivodedova, S. Balshikeyeyv, Procedia - Social and Behavioral Sciences 114, 574 - 578 (2014) doi:10.1016/j.sbspro.2013.12.7495

8. I.V. Shatskaya, Kreativnaya ekonomika 12(3), $305-314 \quad$ (2018) doi:10.18334/ce.12.3.38941 
9. N.Yu. Kaufman, Kreativnaya ekonomika 12(3), 261-270 (2018) DOI:10.18334/ce.12.3.38922

10. Zh. Myrkhalykova, A. Aidarovab, M. Seidahmetovc, A. Abishovad, E. Dosmuratova, Procedia - Social and Behavioral Sciences 143, 491 - 496 (2014) doi:10.1016/j.sbspro.2014.07.421

11. Yu.N. Gambeeva, E.I. Sorokina, Kreativnaya ekonomika 12(3), 285-304 (2018) doi: $10.18334 /$ ce. 12.3 .38897

12. G.K.Kenzhebayev, T.T. Dalayeva, Procedia - Social and Behavioral Sciences 152, 179 - 183 (2014) doi:10.1016/j.sbspro.2014.09.177

13. P.D. Koudahl, Procedia - Social and Behavioral Sciences 9, 1900-1905 (2010) doi:10.1016/j.sbspro.2010.12.421

14. S. Wiesner, B. Horizonte, Energy Procedia 57, 1034-1036 (2014) https://doi.org/10.1016/j.egypro.2014.10.069

15. R. Li, Developmental Cognitive Neuroscience 2, 91-98 (2017) http://dx.doi.org/10.1016/j.den.2017.08.007

16. Ana del Carmen Tolino Fernández-Henarejos, $\mathrm{M}^{\mathrm{a}}$ Ángeles Hernández-Prados, Procedia - Social and Behavioral Sciences 237, 1026-1031 (2017) doi:10.1016/j.sbspro.2017.02.146

17. P.-E. Anckaert, D. Cassiman, B. Cassiman, Research Policy 49(2), 103900 (2020) https://doi.org/10.1016/j.respol.2019.103900

18. B. Shulruf, R. Turner, J. Hattie, Procedia - Social and Behavioral Sciences 1(1), 24162420 (2009) doi:10.1016/j.sbspro.2009.01.424

19. E. Beddewela, Long Range Planning 52(6), $101911 \quad$ (2019) https://doi.org/10.1016/j.lrp.2019.101911

20. Bojan Musil, Janek Musek, Velko S. Rus, Studia psychologica 51(1), 53-68 (2009)

21. A. Yermentayeva, K. Naimanbaieva, L. Sultanbayevac, E. Uaidullakyzydd, G. Niyetbayeva, Procedia - Social and Behavioral Sciences 82, 904 - 907 (2013) doi: 10.1016/j.sbspro.2013.06.369 